蒙古律例と理藩院則例

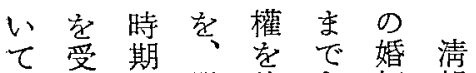

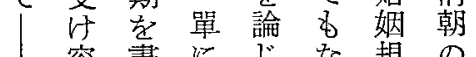

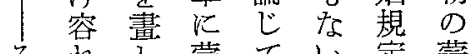

光蒙てい。定蒙

のてた古理。な古

性、の藩 毛人

格一要院つ蒙に

慣五今巷則々克對

毣四世机を一にる

法年紀る る九竞立

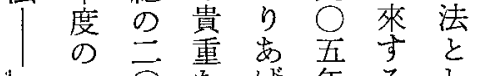

ᄂ二可な将年るし

感 ! 年財て、規て

收 $三$ 代產顿臨例著

載シかで、時が聞

さアらあそ党見す

れ學兰るこ彎出る

$\tau$ 會 家に舊さ蒙

心の年畜見慣れ克

る研代比出調、律

。究飞よさ查蒙例

こ報かるれ會古打

の告け貲るが法よ

論亮て罪中編研び

文盛のと國集究理

は篮り乙法刊の潘

今たアての行有院

の內 ザし實し力則

と陸, 加刑た敒例

こ $フ$ 認主声史

ろシ ス識義國料な

蒙了キさに行とか

苦の 1 基政な住

律研のて岕法る、

例究々はく㜔

火年い刑當々償

關ばでな法時は表

寸、专少規に、義

る林りつ定要いに

唯章、た代先基

一 氐和帒てさ号

のの專の゙こ る

專檤蔮種償 理り法

論古白の主藩た規

交律它研義院它定

で例の究の元

ま成に之刑心固

次果二机罰 5 有
院諸序

則本 言

例

ᄂ 2

關蒙

係古满

律 法

例

結の筑

言成人

立法

䕏

三

蒙 則

苦忘

例古

上人

理

藩 對

院象

則

例ᄂ

た

續 特

法

1

理

藩 蒙

院古

則 律

例 例

の

成理

立藩

息

院

四 例

蒙 1

古

律蒙

例古

と 律

理 例

潘の
蒙
吉
律
例
と
理
藩
院
則
例 
く稿る爾四明こ程據なで國下部こ䇫

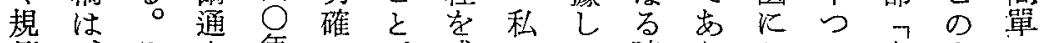

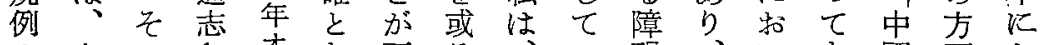

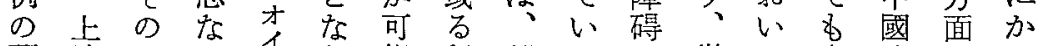

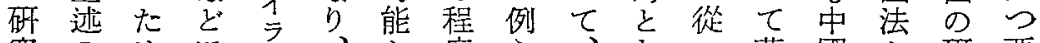

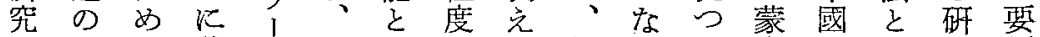
を企に載トこな規つて古の周究領 項圖 \&錄法れりで大例てそ法蒙邀でよ

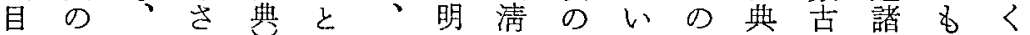
每いこ机・最こら會變た肉㤎に民注と にわのた心近れ加典遷。容原對族目の 公ば仕史八のらに事なその典す市のに特

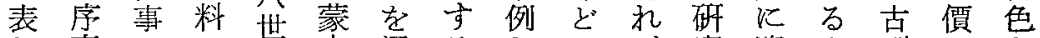
ᄂ 章の $の$ 紀古通るなと代究溯立刑いを 々と軸援悲法じどは加につ法法す浮

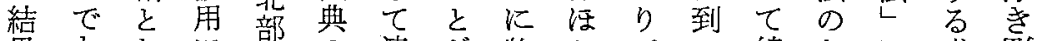
果めなに蒙の淸が收とでつ綿なに成䧓 といるよ古原朝で錄んなて密か收果り

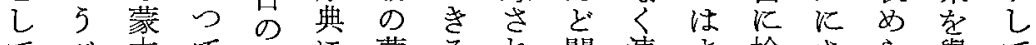

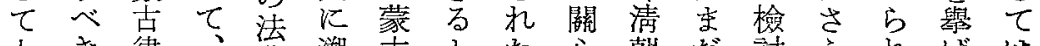
上さ律、典溯古とた心朝だ討え的げは

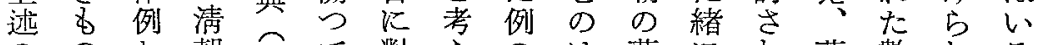
のの怙 朝て對えのは蒙にれ蒙數れる

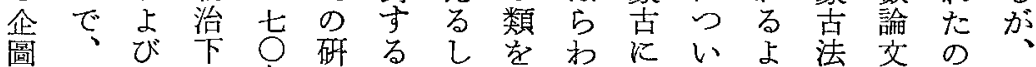

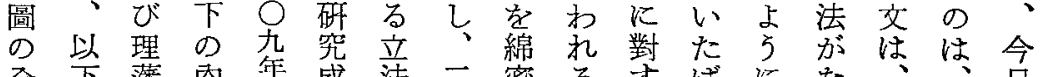
全下藩內年成法二密る步ばにな、日 般 推院 蒙 公果の 法にこるかが拈こ故か に敲則古八公追と立りる生れ仁ら 及を例にジ就かに跡が法でた方ら茾見

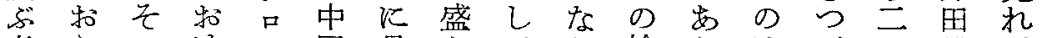

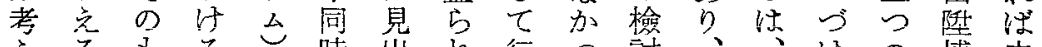
光るる る でにの法と代さた汁たすをたた法士 料

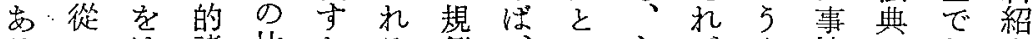

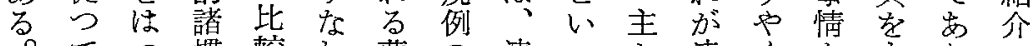
てっ慣較放蒙の清つを清くを市りの

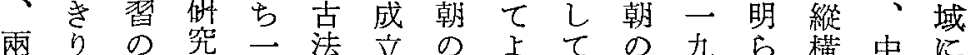

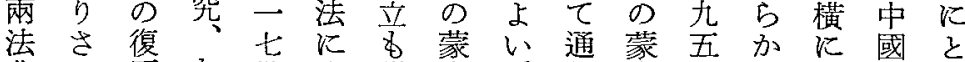

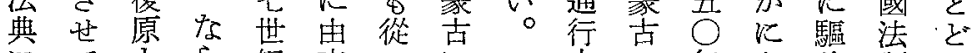

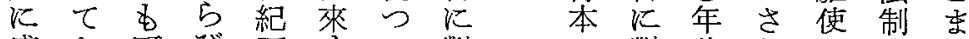

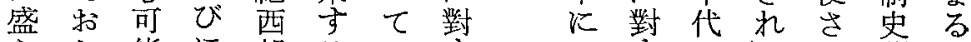
わ的能に 部学 こ たばな遠古定を法豆立坐と二・就 蒙なる通のの明的 法法にこ八刑さ 古らと志法性ら取带のなる。法る 法な考稿典格吕扱芯研少で九篇を

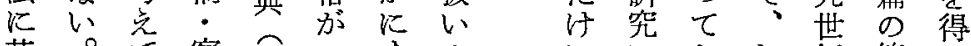

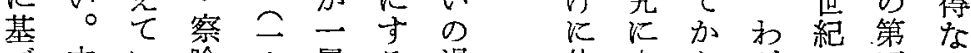

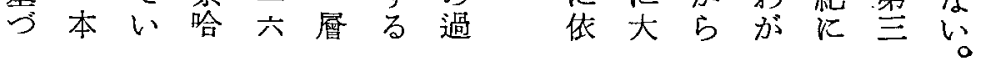


蒙古律例と理藩院則例

設 點 本 と

话名的簡

にこと

命 万简

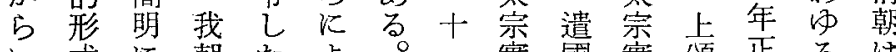

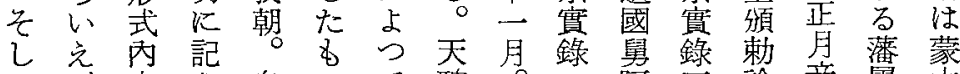

て

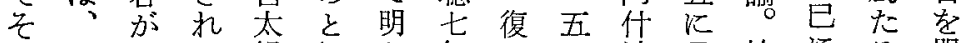

の 明明て祖解 5 年以澾見於に方服

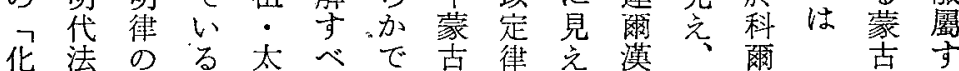

外々蹈よ宗きあ諸令る等同沁西る

を法 ゆ、東 万頒布史欽七曼海:太心

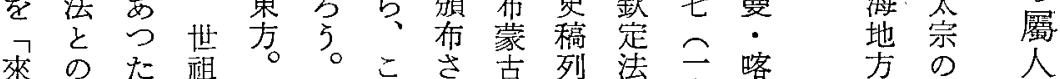

來のた祖。こ古列法云愘方の人

降間この民い记諸傳律六爾の崇法

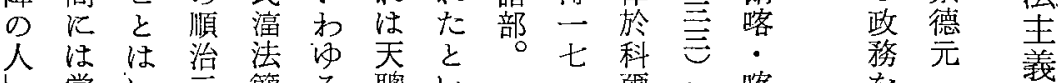

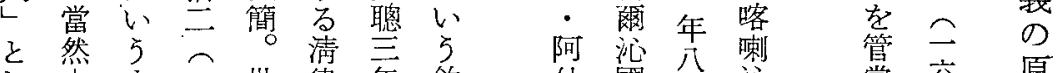

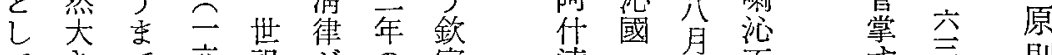

てきで六祖がの定澾・癸五。方言則

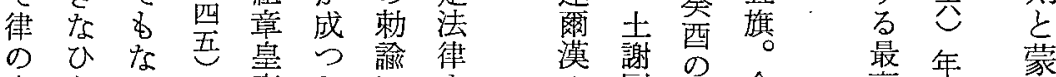

本ら心年帝たにま

交きが吾。の市た

にが、韋撫はるは

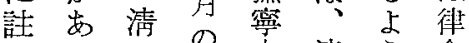

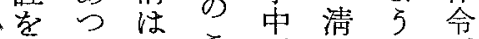

加た北こ夏朝飞落

乨清民方氐修典我い

心律族、明窑朝和

た乎の以嚄八制ゆ

王來章 $\bigcirc$ 度る

大た朝數。・を清

清明で间頒 刑遵律

律律 あの行一守で

例にる修大の卞な

按從少定清冒べい

語つら品律頭きこ

卷 $\tau$ 、加。 $匚 こ \zeta$

一䔬光化怕

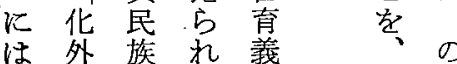

は外族れ義重ち

余报步重占

犯 の 清各述

條意堷得般る

をの基宜的と

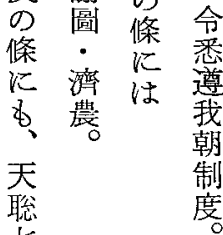

年

K

力

讨

$\tau$

洫年蒙

閣早人

た

5 蒙對

乙古 象

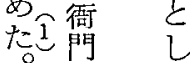

一辛た

方眇特

艺直別

り $\overline{\text { 年 }}$

前

太こ

宗れ

の を

聡 理
潘
空
改
三 


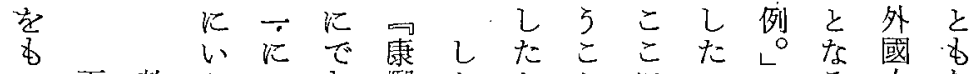

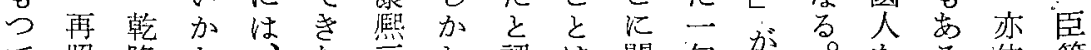

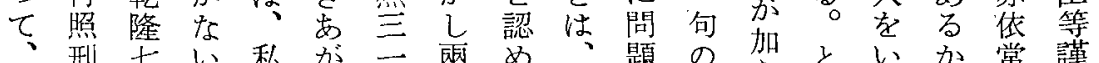

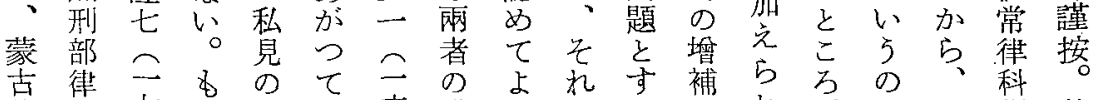

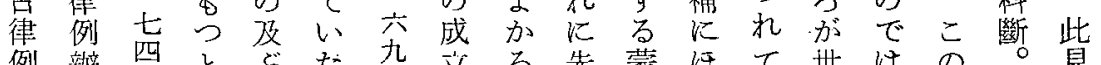

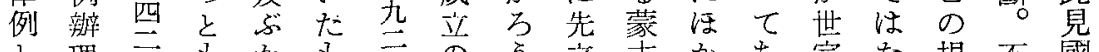

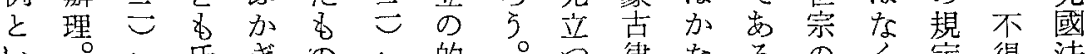

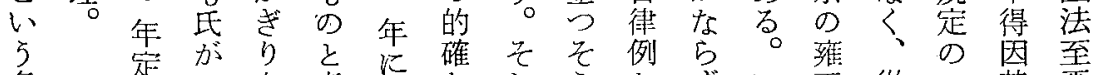

名定

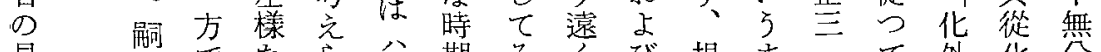

見後でなら八期そくび規ますて外化分

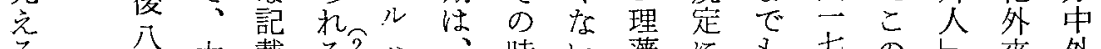

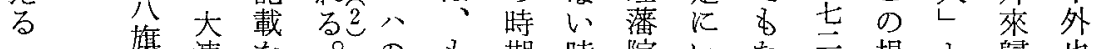

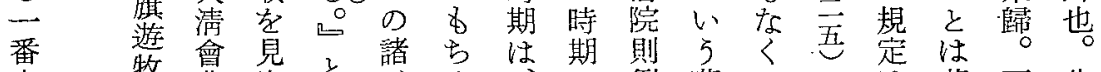

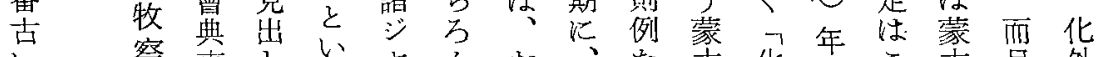

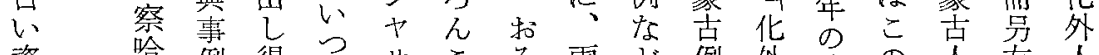

資哈例得て サこ去兩ど例外律の人有人

料爾巷必て

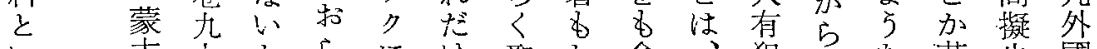

、古九からに注聖し含、犯後な苗也國

つ偷四ら机律で祖くめ清心。外人。來

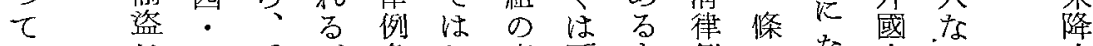

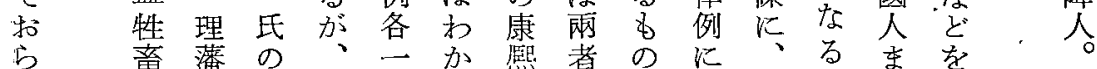

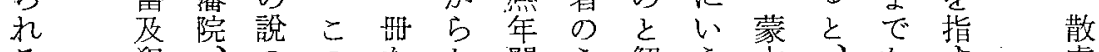

る 犯方のをな間 5 解 5 古、を夺。處

$\infty$ 别刑結立放

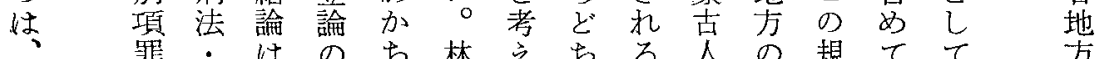

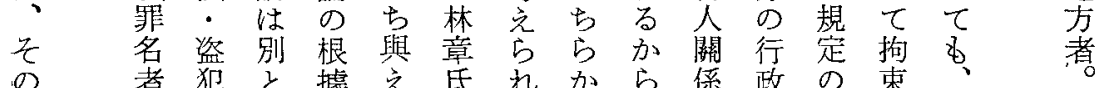

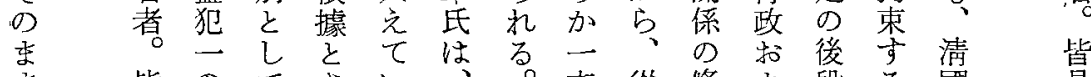

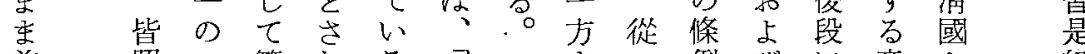

尊簢れる蒙市つ例びに意と。既

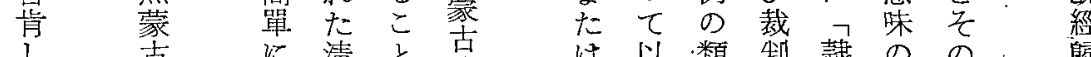

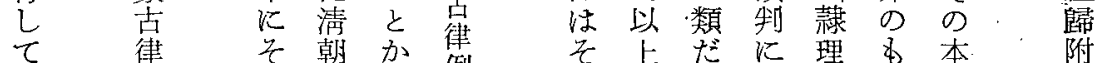

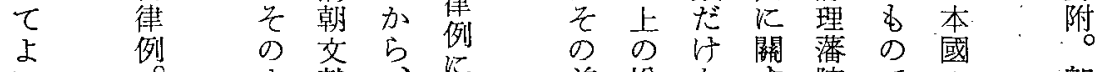

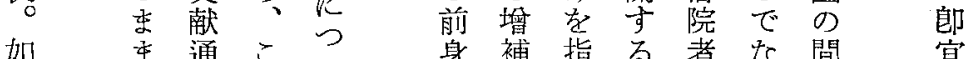

蒙受考古

古潘頃し るなの別乃こ往體

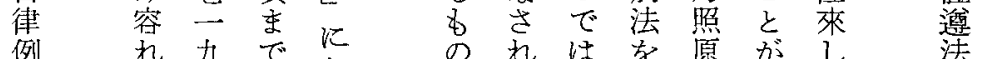

㱚、杂九でに

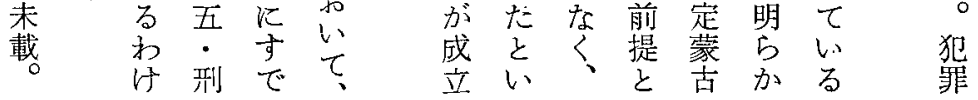


蒙古律例之理藩院則例

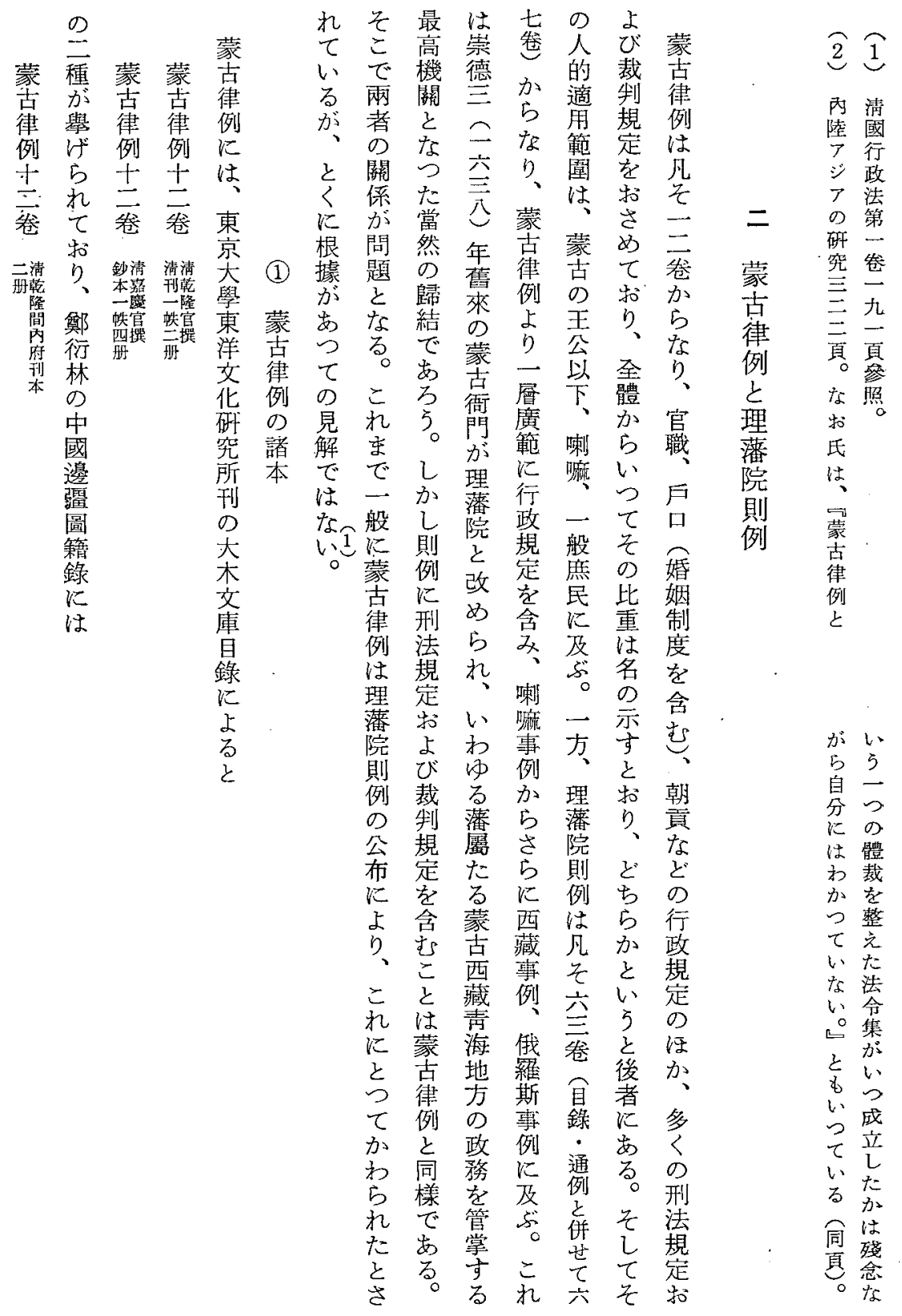


之乾 增 例いの刊 の 科の る隆訂の。規本さ重か军 嘉五則依と定はて印らる 慶四例據こな、本邦こ ○年驾し ろ と、凡 こ 年 えの大年二ら版

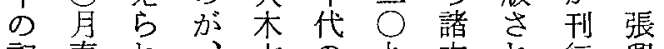
記奏れ、文の析れ行興

事請て嘉庥 明條のてさ磨 を等 い慶本ら間いれ

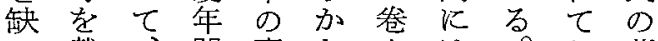
い載、間嘉な六は。特蒙 て いて 木 刊官の盜芉 るい交本拱に賊の ○る庫でのつに異 そこ本あ鈔い乾同 し, の品本て 隆 が て、嘉こ深五市 增大慶々情与四つ

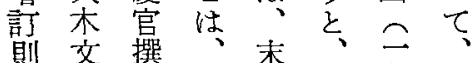

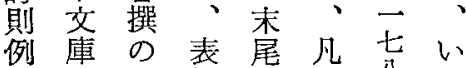

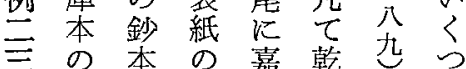
條乾之裏铲隆年加

洛は畫一年—の

愊同に○間 、撰 $一$ 上 00 月 統 乾のでつ二む月に 隡刑应て分のの分 五本以明年で奏惊 六之。无方請る 年同同吕年つ坛 一し本でのて告と 一

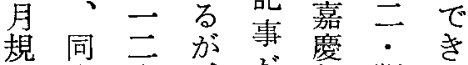
定交卷 驾年斷方 以庫二こ㐫間獄。 忐本二れる。の

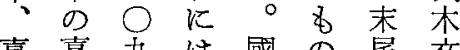
嘉嘉九國の尾交 慶慶條全學はに庫 一官で二文二乾 本 九㽞、二稙つ隆の 年の炎卷本白乾 部鈔の $の$ 見二隆 示本な 学蒙出年官 加見にに律な月の b古

、然

成 考

紀 畫

七 目

七見

二 え

䘮。

㽞音

年 康

月

流

當 年

の

蒙

古に

息は

邦當

政 時

府の

興 满

蒙洲

委 國

會 安

加總

）署

そ查
二 元

に九
究 の

室 五

蒙桑種 蒙 蒙蒙蒙

原 が古古古古

交揭律律 律 律

庫证例例例例

删南

年

领 次以

印不る 嘉國 删鈔册清四清

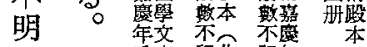

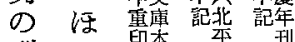

刊吕留本虔燕本

本 $に$

方

女 舊

り 東

在矿

壱 究

北 所

の

中 干ा

贵 本

研と

究 鈔

院 本

歴 各

史 一

語

䎡

究た

所的

K w

\& 和

机

万

L

京

都

大

交

部

東

洋

客 


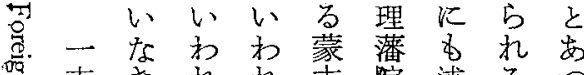

方きれれ古院述る。满院藩

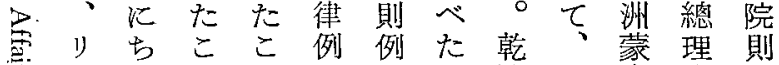

宁方とをでのよ隆こ古內例

なザいは編一う琶の漢外の

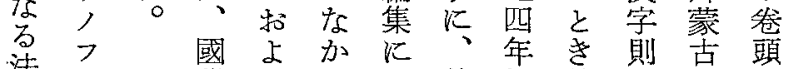

法

典

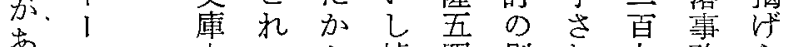

文に

と文

乙る

$\tau$

次-

青 公

木 九

富簟

郎 五

氏 四

忧年

扎保

老 制

它

の さ

譯 れ

本た

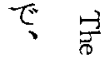

ᄀ鸪

分贾

九 总

年

の 㞼

理 0

藩主

院

則

言睪

出菅
本にと據四則れ 九務

全洲方と一の理

二字 5 な 0 條 藩

一. れ与月數院昆蒙嘉例

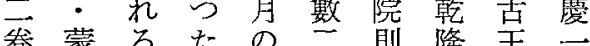

の古。乾 奏 0 例五 公六立

来学

尾・五唯

に漢炎元

加字 5 年 年

九 $\sigma$

條鼣

ら䪭り

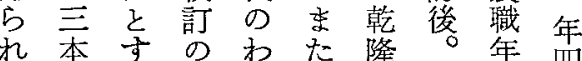

れ本すの就

たのる 則方辛

ああと例る蒙四今 朝

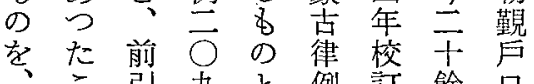

增々 慶條し

訂品桂と佟則

則知の迤数

例 5 上

とれ 奏

稱省氾亦新致九

乙。过 $九$ 夺條

$\tau こ つ$ 的少の

いとて交とし 修

るに、庫い、訂

の蒙蒙の弓太文

以古古乾こ杰り

之律律隆之文始

$\checkmark$ 例例本に厙め

$\tau$ 加怔之注 95

ほたたて隆た

と則則披て本こ

え例例見文 力 $^{\circ}$

ぞとでるまが

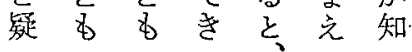

の霂考所年例た條

亦意乾机
加逆点

でにら章

军乾れれ

る隆る。て

年方各

代、こ

以邦の

後譯 增

の本訂

あは 則

の 一 例

品 二 学

一 卷 載

○一出

$8 \pi \tau$

广四

以條る

なでの

そ. は

乞 木こ

の 文

原庫 本

本本廌

¿

ま 乾 で

隆安

た管つ

b 撰

の

が官 い

大本 ま

木にの

文なと

瑓いこ

の乾

乾 隆 編

隆四纂

本六年

と年 代

は三の

同月最

で豆新

なの ᄂ

w聖 W

乙 居 6

之 0

明載 と 


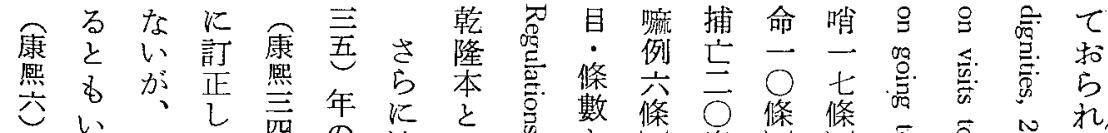

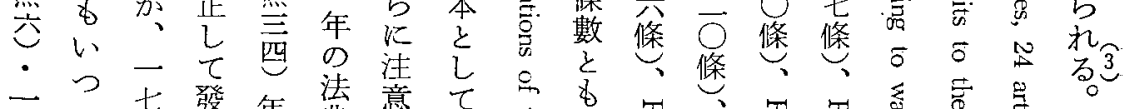

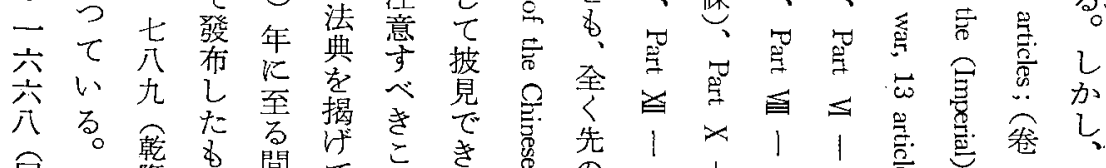

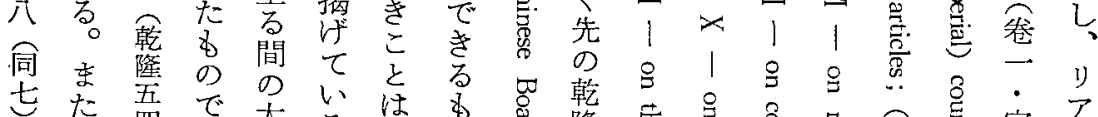
七た年 の゙

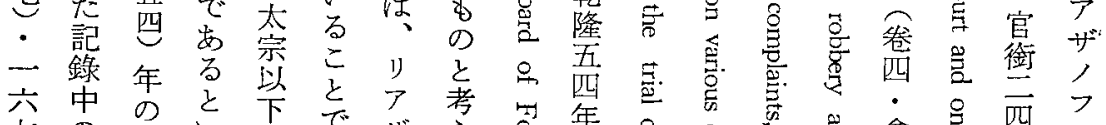

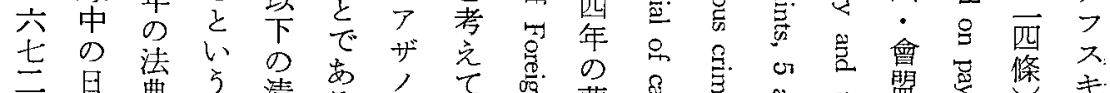

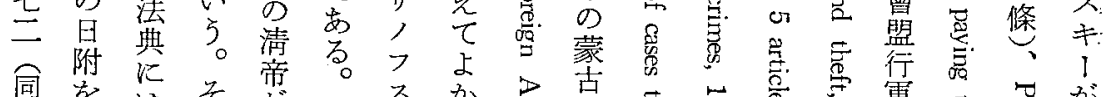

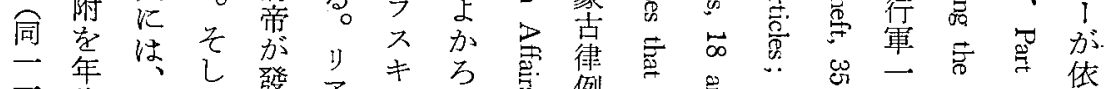
二帒こ て

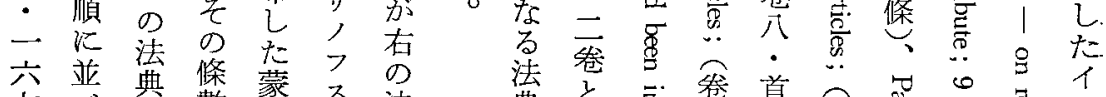

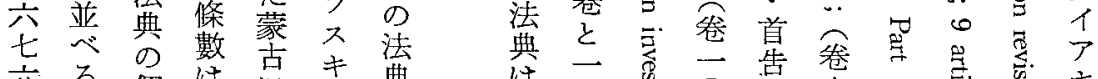
六る 個

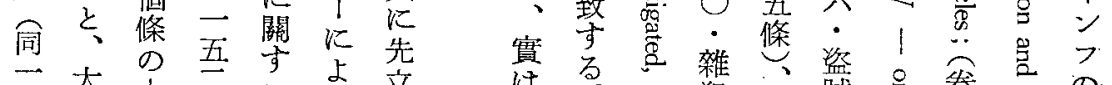
五 宗 部條 る る - 无 分 六聰く

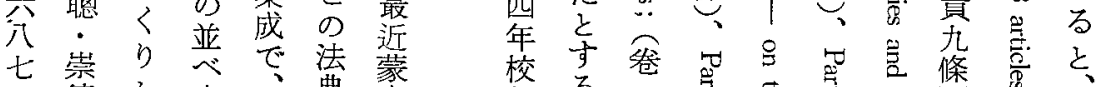
德加方。带古 同中方に二六は品 三、六は六二寫 六世的心九六本 - 祖て 一の心な康九發 六順る る 康茲見 公治と體熙蝮さ $\bigcirc$ 中、想系吾恶的 同聖集順 年 年 无祖 湧 聖吕 只 九 る 当祖 5 公 - - 六向傾 認 方最六六 六六肪ら終九康 九七市机的五熙

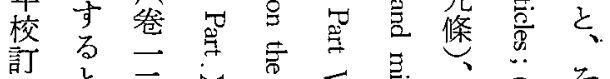

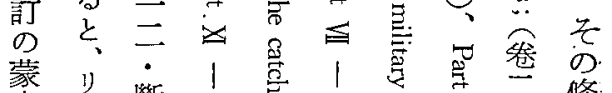

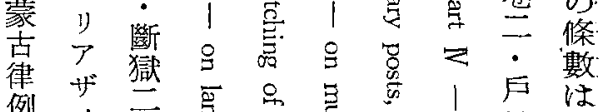
例 ザ 二

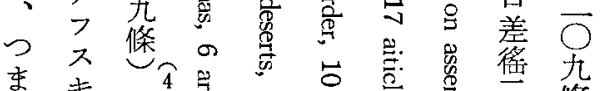

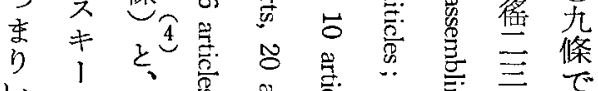

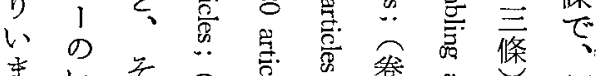

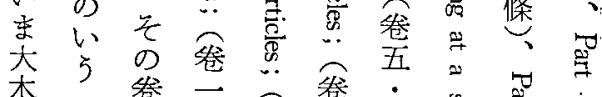

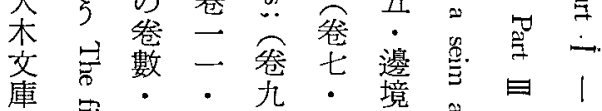

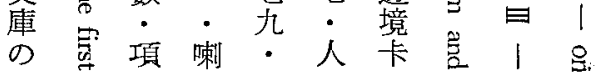


蒙古律例と理䟖院則例

年年頒て 凡 一 て を 以九し給いそ六修と古かつの年聖

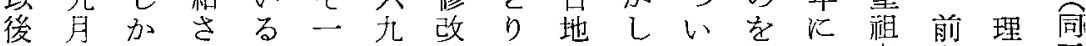
ののしれと五六さ市方考て 徹は實所藩䚻

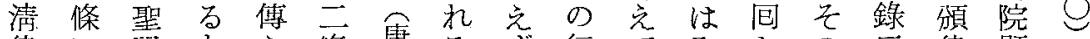
律 に 特つにでれ排吾と成括る所、例に徹崇六

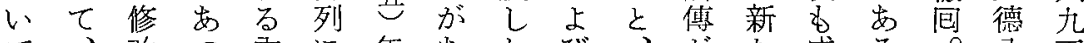
て、改つ內に年あたび、がた成る。五

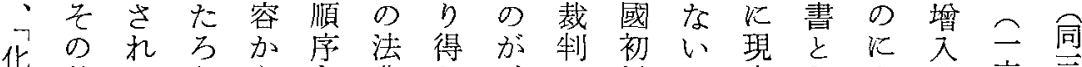

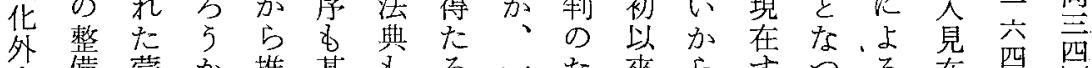
全 備 蒙 古 推 基

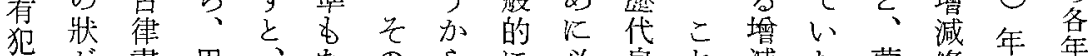
㤎芯畫用、なのらに必鼻れ減た蒙條頒年 條筧は吾

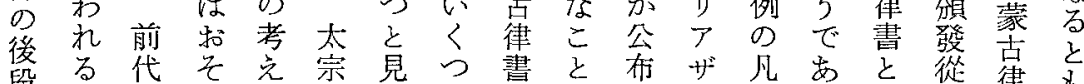

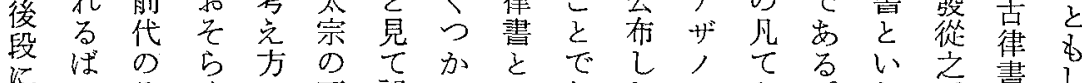

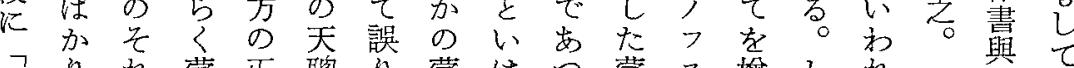

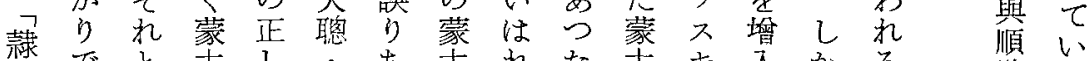
理で

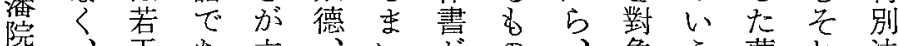

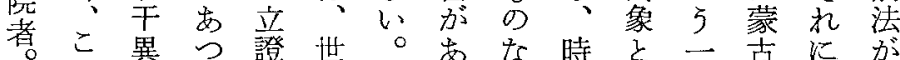

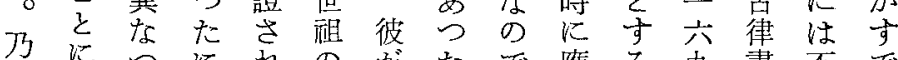
昭につにれのがたで應る九畫不で

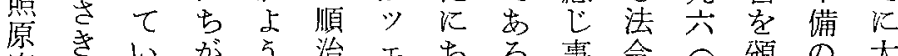
定に心が

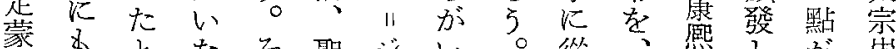

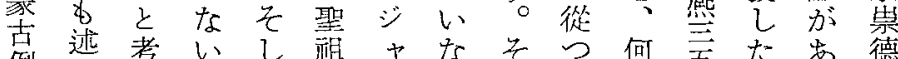

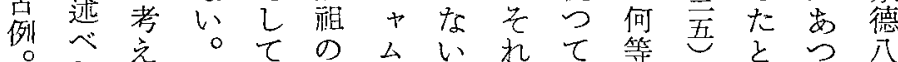

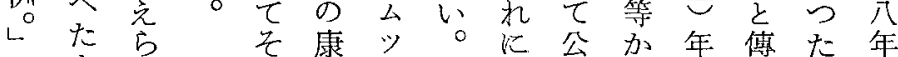

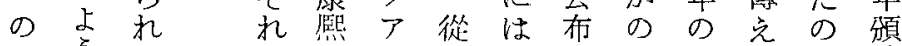
一 5 る

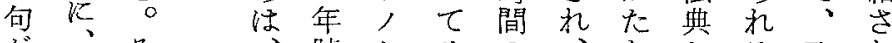
增 世学 れ

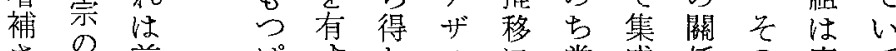
さ夜前守た, た常成係の康て 机雍引らる知

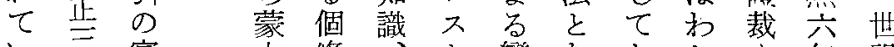

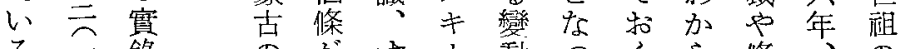

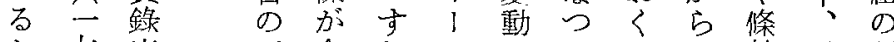

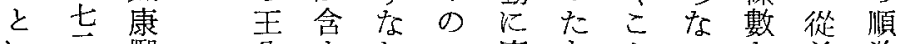

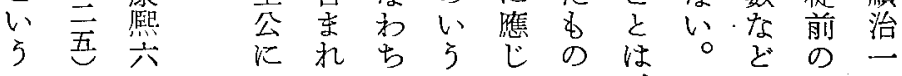

एव と

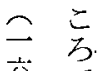
忩 万人 七 康 年六 定 ○ 增 六 減 兊 一年 應 月 行登 交邱 


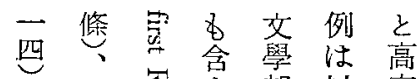

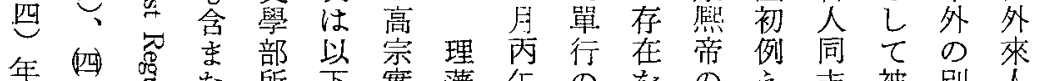

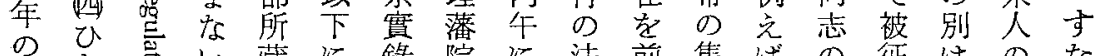
のき部き心藏飞錄院に法前集は心の征はのな 部仓念邦桑述二奏令提成太犯服な犯わ をづ另譯原芒吾蒙

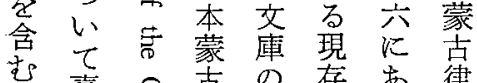

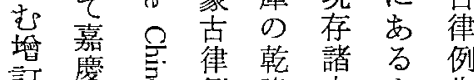

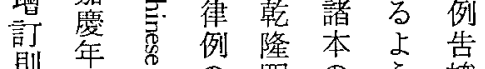
則間四の.四の引䇋

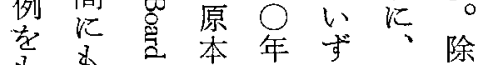

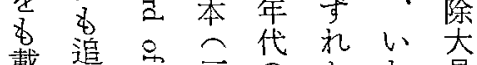

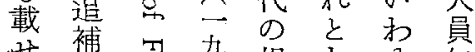
せ補品苜規各ゆ無 國加 前焂例出る庸

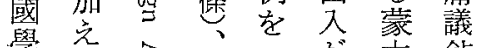

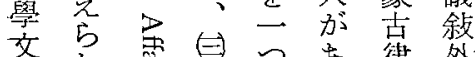

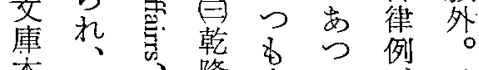
本い心隆含た㤎棓 小いす五含々牌 原卑な四な思の在 本等わ二いわ體犗

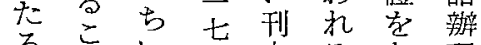

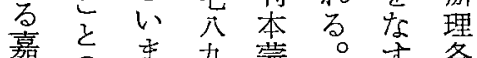

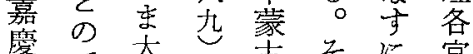

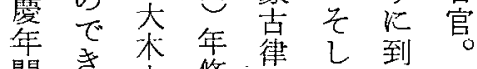
開き齐修例乞到及

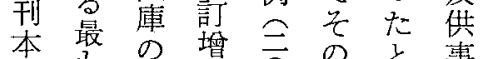

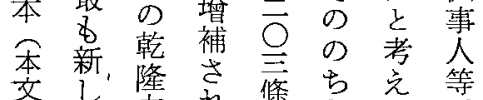

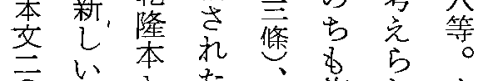

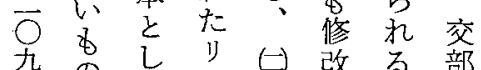

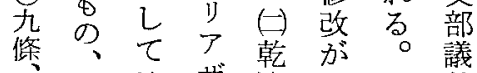

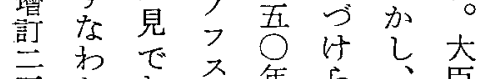

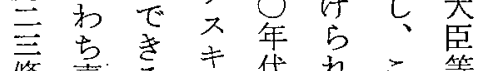
修嘉高袋贷杂等

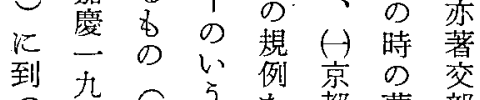
菿三5都蒙部

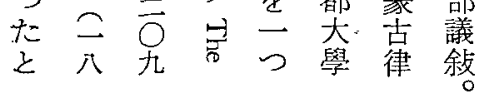

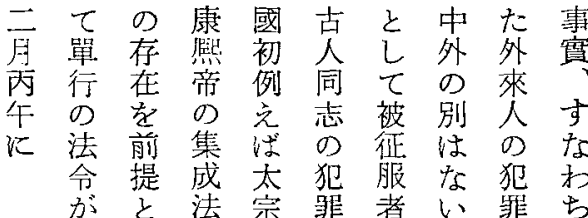

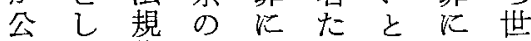

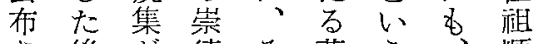
巳後加德古蒙亏、順 机段出公の克考嫢治

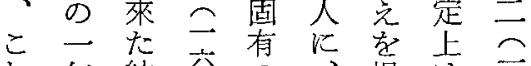
れ句結酋の、根生空

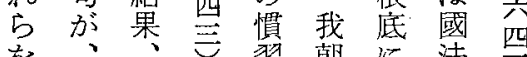

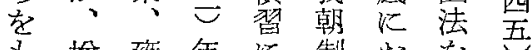
㒄雍年飞制拓飞吾 集補正蒙低度心遍年 成さ主苦拱のて用の

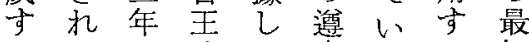
るる。公た毞上初

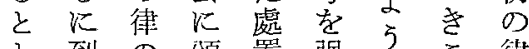
と到の頒置强 5 己得

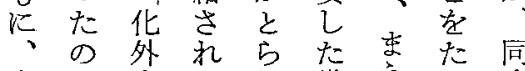
康で人た机賞党て條

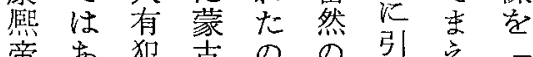
蒂市犯克の留竞

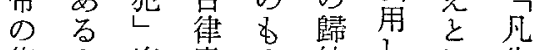
集委條書生結乙化

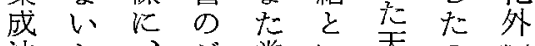

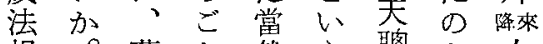
規。蒙々然克聰と人

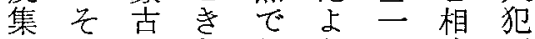

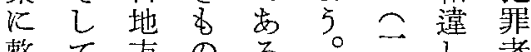

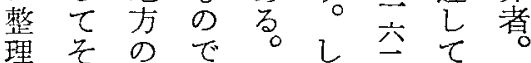
を行な无无严

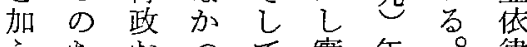

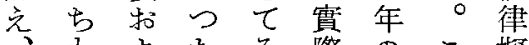
与上每際のこ擬 畭な゙加のの态れ断 隆括裁々基裁宗飞致 六時制思隻制の时灭

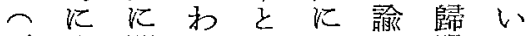
應關犯さ怯以服っ

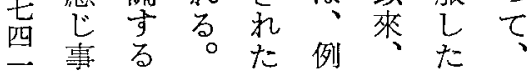

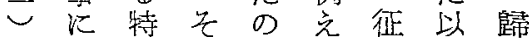

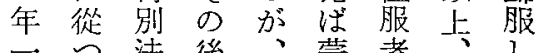

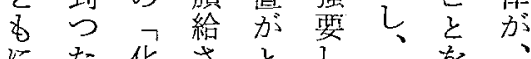


蒙古律例と理䟖院則例

俱 院 理

末舊院

經 有 則

纂 滿例

入洲の

頒蒙冒

行克頭

臣字原

等 則 修

声獎烈則理 品

自原院 例

畭杂則と

隆 條々

十自て成

吼乾揭立

年 隆涪

以五 5

來十机

應 四た

行 年 嘉

篡 校 慶

入 訂 二

案後 六

件 乞

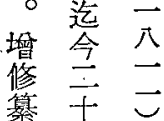

入 稌 年

永載四

遠所 月

行有 八

以奉旦

仰崄慶

副旨桂

聖及㤬

䒠热 㯺

润 陸

外 續

蒙條

洍 事

僕 件

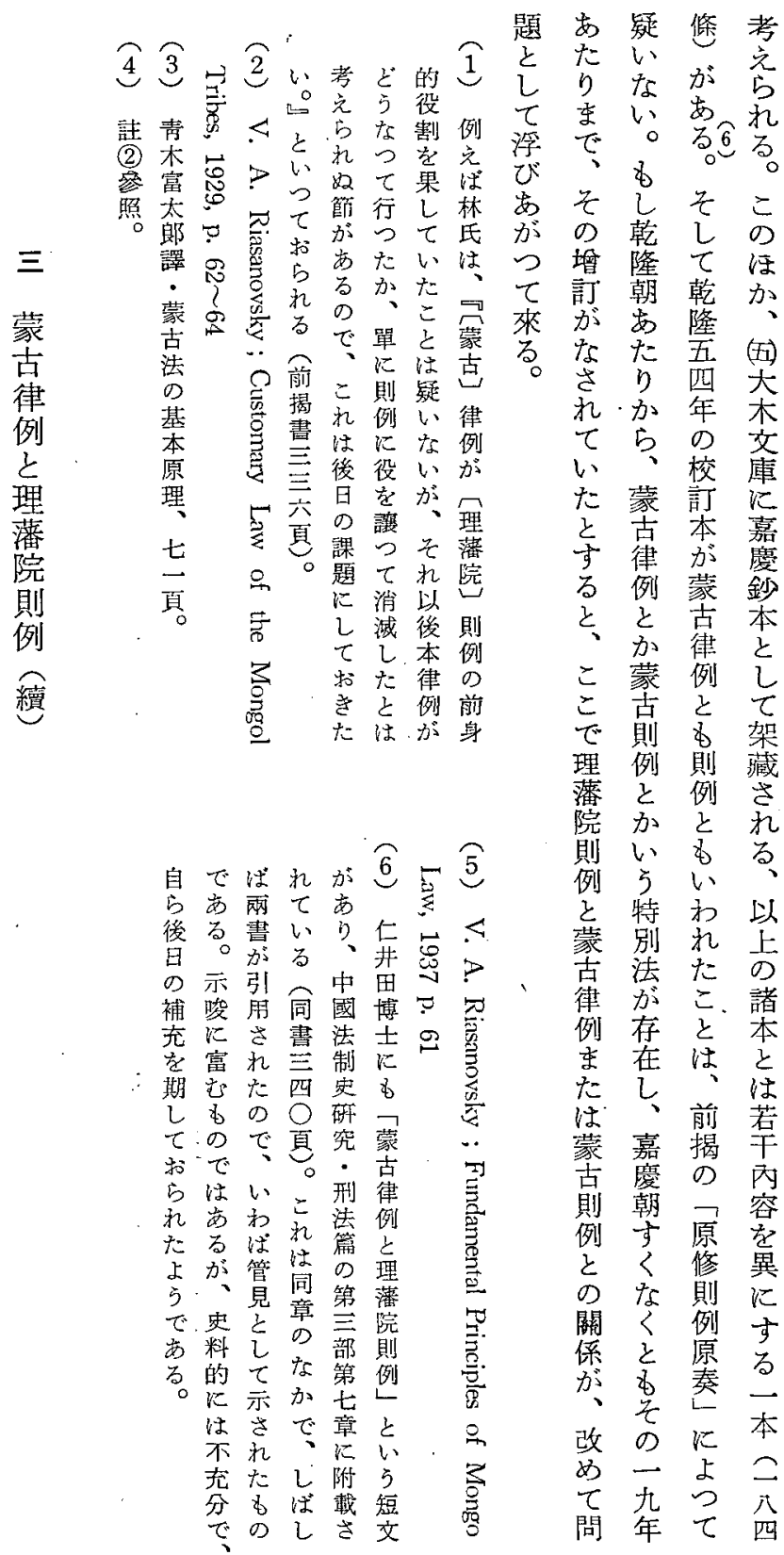

題市疑悠考 ᄂりなが市

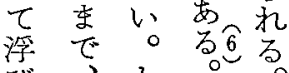
劣之学こ 增隆て㾁 訂朝幹か なた五 (7i) さり 四大 $\tau$ 万 心、校单 た蒙訂に 索本嘉 る 例 蒙 鈔 と古本 こ蒙例乞

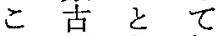
理 例 則藏 藩 と 例さ 院かと视

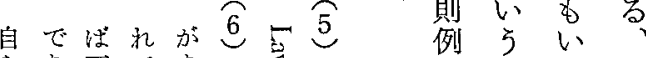

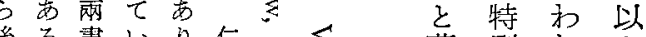

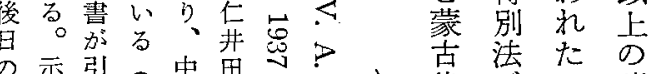

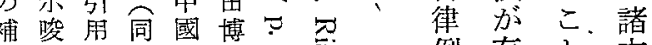
充飞さ甾法士の焉 期它た四史子矿、は しるの○研フ至は、前若 てので真究蒙 . 蒙嘉揭干 新い。刑葏古慶の內

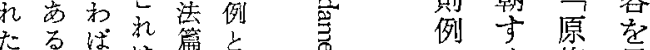

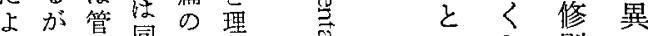
う、見章第藩 のな則に

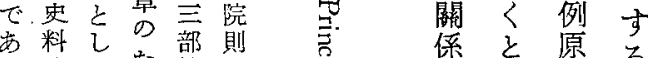

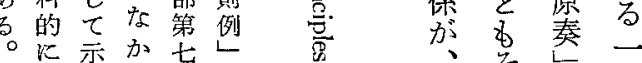
はさで章と品改の体

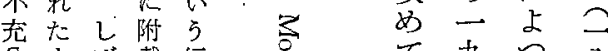

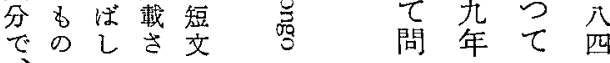


にと、 で閱 し

そ篡條將同飞滿々乾需删時院津部令る之.

の修。舊時漢洲乞隆譯改僅向は則を志至

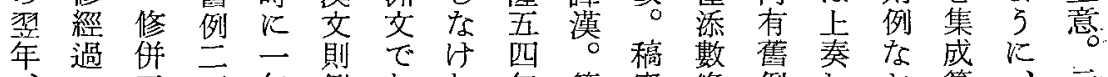

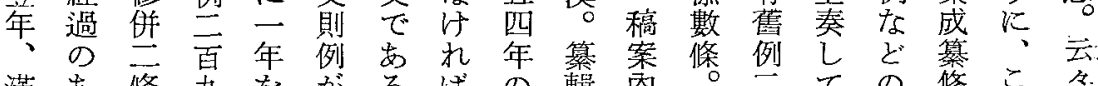

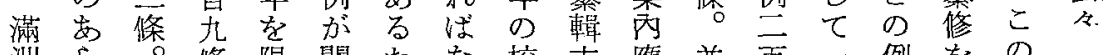

洲ら。條限閶たな校方應亚百一例をの

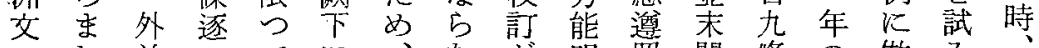

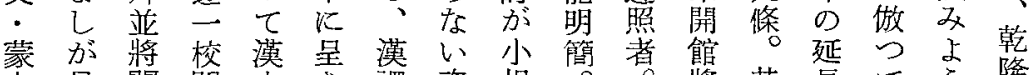

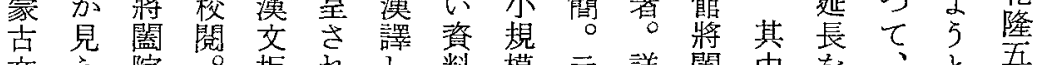

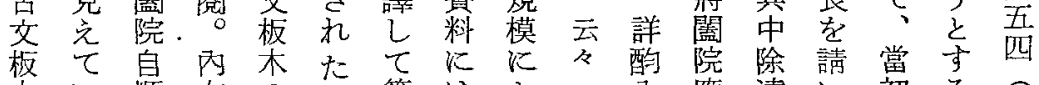

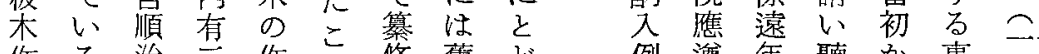

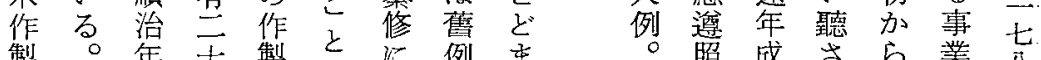
製。年干製之に例玉照成さ到業元

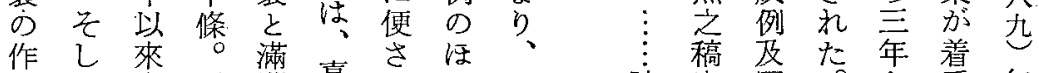

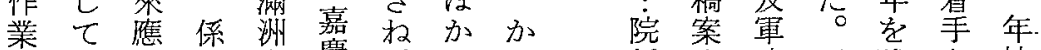

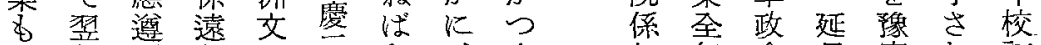
完年照年・石な、今初行會長定机訂

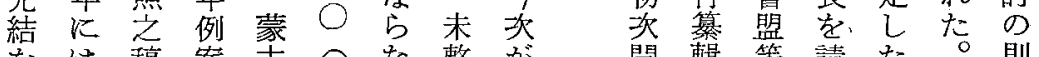
をは稿案古气な整が開範請た。則

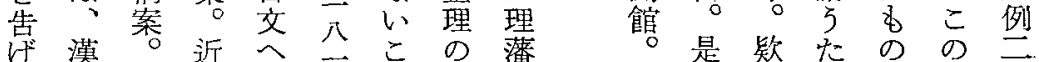
て 交 譯事

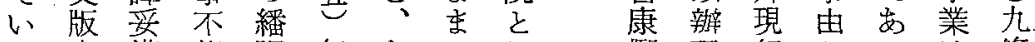
る木漢能譯年なのし腎理行とつは條 ○の交援を二ど稿て, 年事をした同す 作。引請二方案則 以件例て离じな

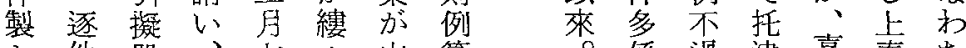

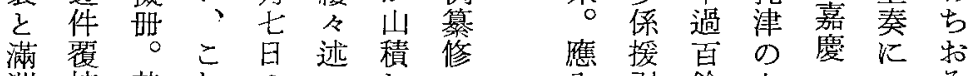

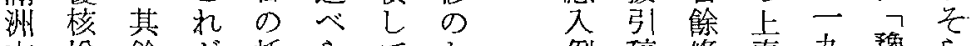

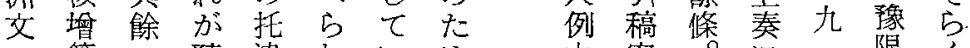
- 悬 一 聽 津 れいめ 蒙五百さの活の 古百八れ則あこ初 交示十て例当古次 譯六條る本とし筫 の條。击向加修 作。西 こ成吕名館 業通修ののくこ開 落共改上四礼館 完七二奏奏年らで 了百百中湟 七士七に明歲案る さ條公占等均め 稿案踓任二限々 案於は公年蒙

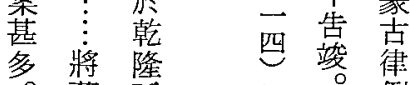
。雀五年 ᄂ 县例四吾离底

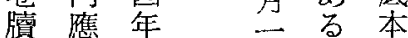
药面奏五上的

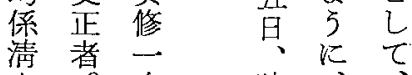
清者㳄時只? 交穻次時爾 必議其長涂後 
蒙古律例と理藩院則例

蒙

な

5

び

K

理

藩

院

例

等

礼

ぞ理

机藩

成院

立 則

例

$\supset$ ह

w $\sigma$

? 関

以 係

上

叙

述

t

s.

b

b

党

考

克

る

z.

前

者

$k$

3

W

证

嘉
則々

例

原 つ

奏它

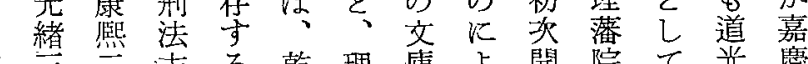

淸だ籍らくとつ部の

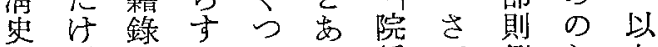

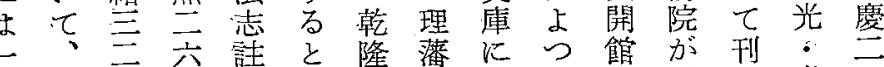

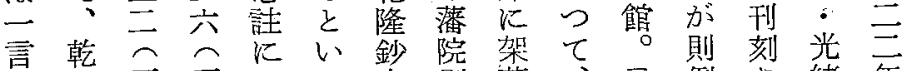

四安隆卉六はつ本則藏、云例さ緒年

与以杂公、て

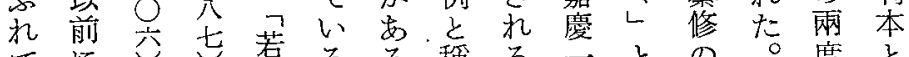

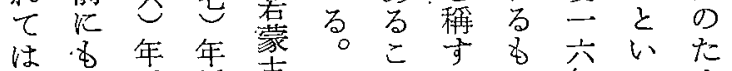

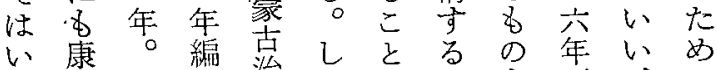

な熙理訂

w云潘 的

六院 理

年 綮藩

編 鳳 院

訂 理 則

の 藩 例

安 部

分所專

安以雼

る 改統

上雼 治

5 理 蒙

藩古語

心部人角元

$\tau$ 例 的

い。

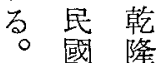

乙変

少韭

L 洋 慶

乙 政.

れ府 道

与和光

の國

乙尼 光

と 筫 緒

に統 各

治 朝

心時 都

て 代 有

恪都增

原暫諼

修角到
浩务

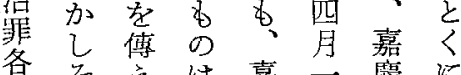

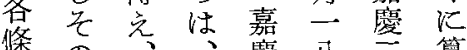

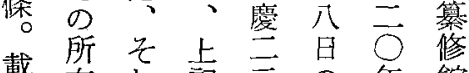

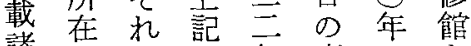

江注琞度一を

鳌嘉刊栍二開

い客愿本的司い

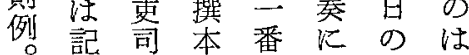

䟿。苦基則

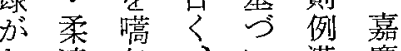

な遠笑、心漠鹿

、满々以て本一

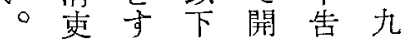

一若る道始成年

方司学光无

中亲考光热素月

華㟟占緒の纪五

人港机等飞百

民更る刊始门の

和司々飞当或津

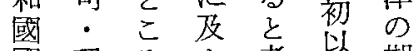

或理亏若著岀期

務刑㤎で紊蓝限

院洼鄭心占丵延

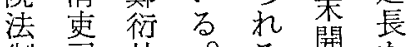

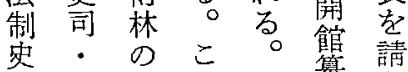

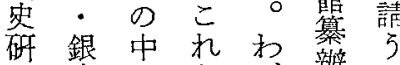

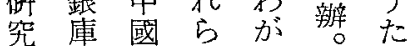

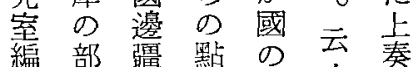

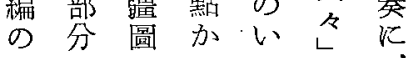

て清管赤上七

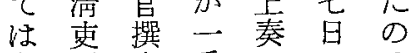

共左。本系自托
度

續 て

纂披

改 見

修で

がき

加

之 欽

万定

れ 理

潘

光 院

緒 則

至 例

二

年 卷

潘.

院 七

が

理 藩

乙成

改 立

万市

证

万事

子.

欽 要

定当

藩こ
部の

め 


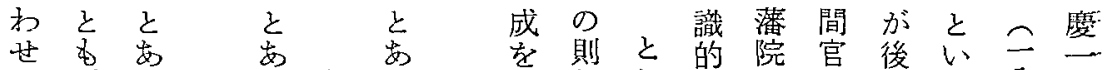
て稱る 蒙る 將る 此奏 例こ則撰 者 5 八九 み L な 古 の 蒙 の 次し の 万考例 の

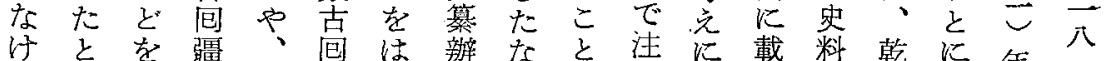

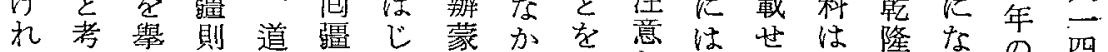

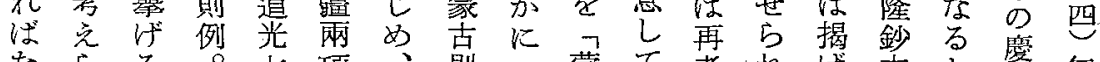

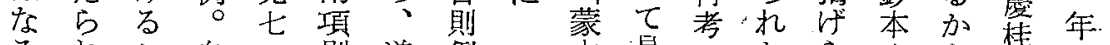

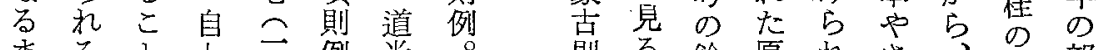

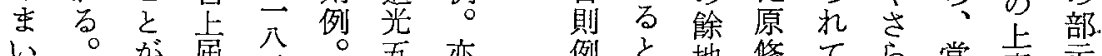

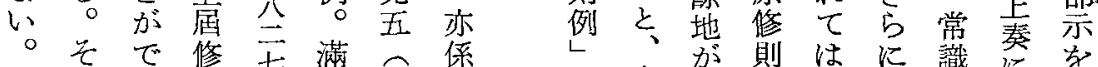

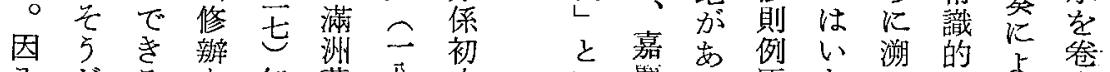

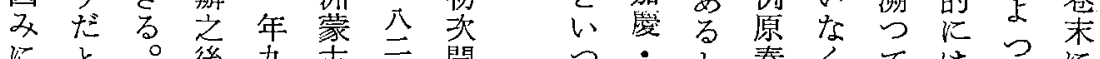

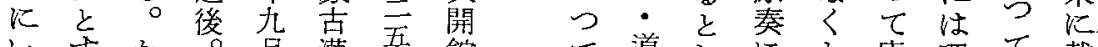

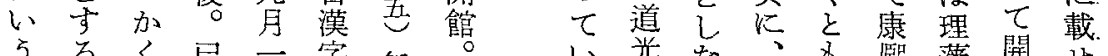

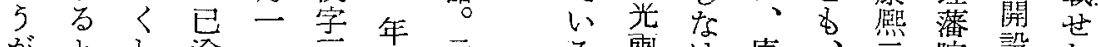
方と、

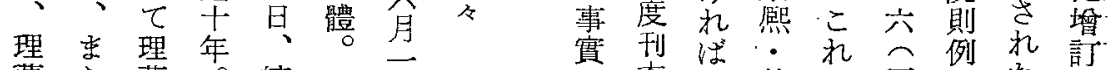

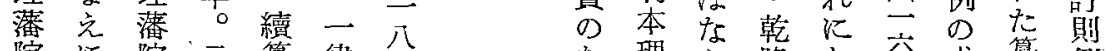

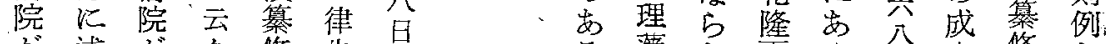
が述㤎々 修 㤟 四 䉪 改成 續 部た修さ纂 對占 象に則則改

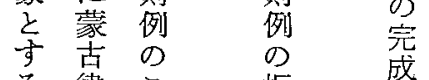

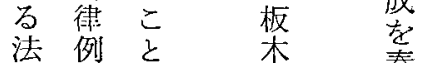
合の学 の 奏 集之理完成究 成を藩变 な た 院 翻 る 潘充 之則。のり年よ究 に例 則 が官つ篡國 氣の例

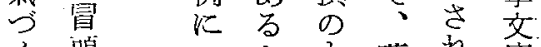

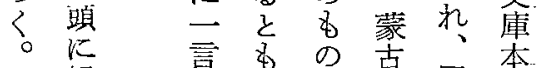
例揭 生考加街同 总句紊例三原

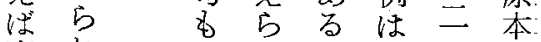
嘉秃。水亡元口方 鹿たれな学た公最 二原 て ○修 心出記吸七 新 二則な 5 述 收 八例 以現葲出年々 の 則之奏 学例稱向 国之文な

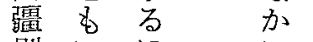
則い淰 例 之た K 5. 蒙 が考古 い充

五 奏

$\checkmark \infty$ 年な 托少 津 則 ᄂ 例ば 漢 L 本ば 告こ
七存り机禁後 七の、をさ者 多嘉鈔看れ比 や は道所得の 光在る加は。 前兩户 0 最嘉 逨度康と的慶 の 摼 こ 古 二 
のが數な行乾ま副の編典なか四てつる

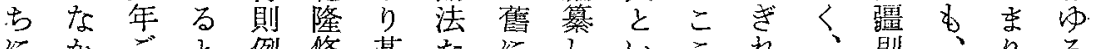
にかごと例修基た汇しいこ礼、則、りる はつと、を正本る復たつでる蒙例い國理 各たに定律會法條しもた清な古之お初藩 部。新例に典た例て $の 0$ 朝い律併ゆの院 院一修一くでるっいをこの事例立る 蒙則 ご 方 $○$ は 會例る、の成實のさ理古例 と、新五入事典し康會文だこせ港衙は、

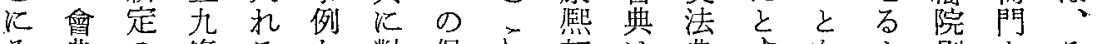

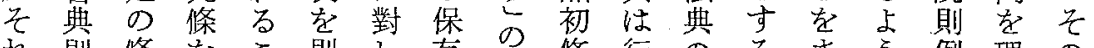

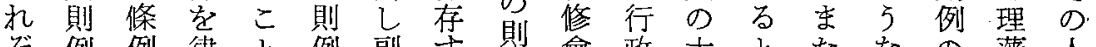
ぞ例例律と例副卞則會政太主たなの藩人 れのを弆內 を法べ例典上樣、蒙場適院的

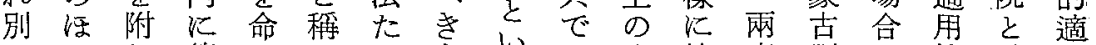
々 か 加篡 じしる す

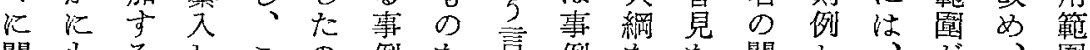

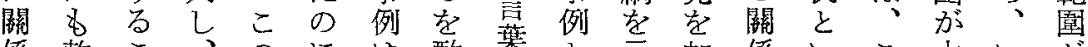
係乾こ、のには酶枼と示加係いこ主い方

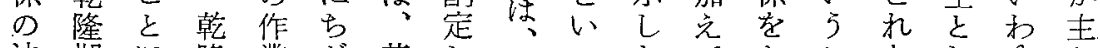

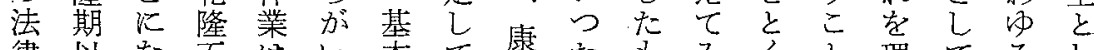

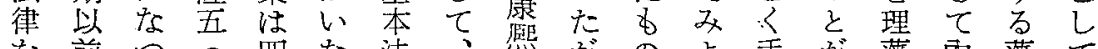

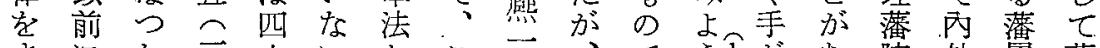

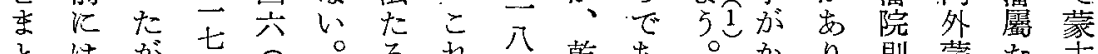

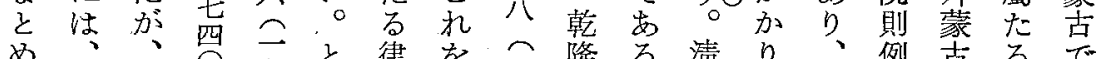
め、它々律を た六律

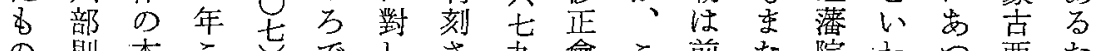
の則本こ导てしさ會こ前た院わ的西た

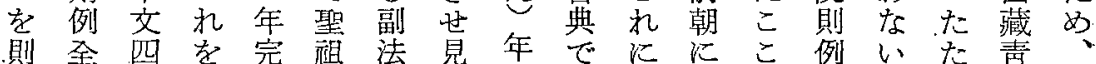

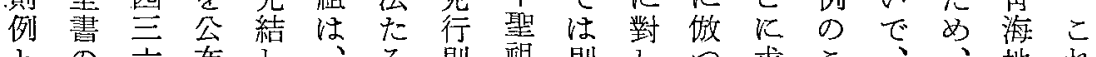

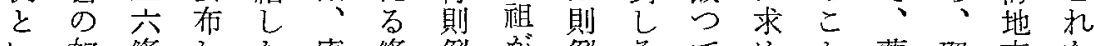

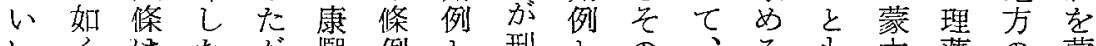

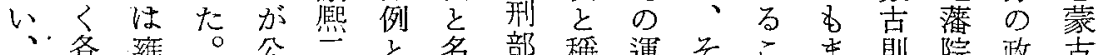

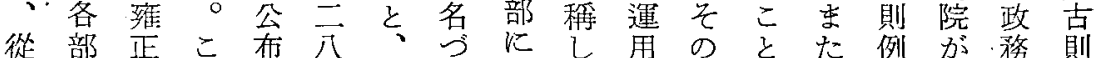

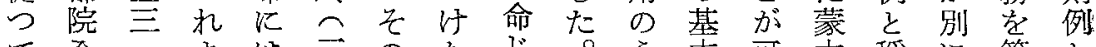

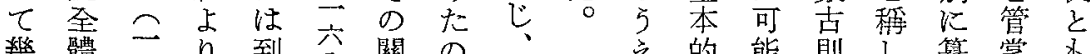

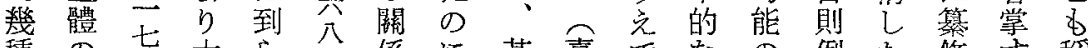

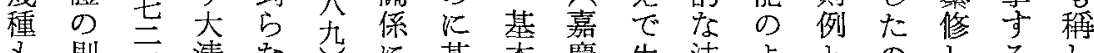

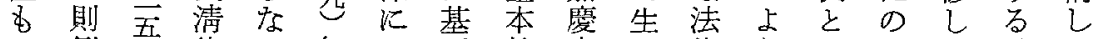
例吾律加年括ら的度心律 5 小たて 最た

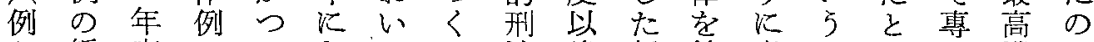
党編度のたなてと法後新綜考こ思ら機で

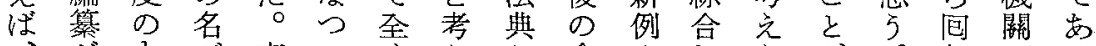

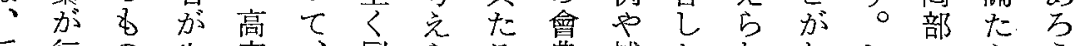

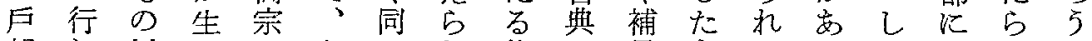

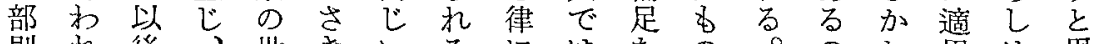

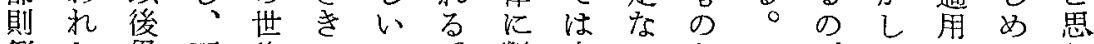

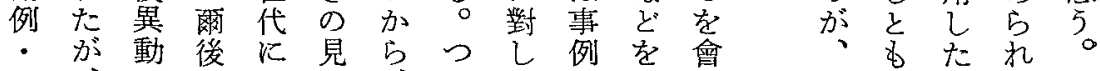




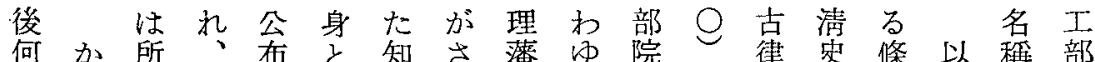
度く在々し考識き院るご年例稿例上を則

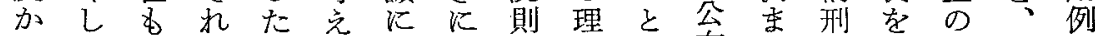
のて記はの占基聖例藩に布た法則淸まな 續私さ原は狄䔃し院別さは志例朝た 纂は狆修、るき實々則々れそ註と成事 を、て 則乾飞文錄は例飞たのの稱文例ま 經蒙は例隆しのに、の行大前いし法のた て古い原ょた著見のご政清身 $ら$ 典舊度

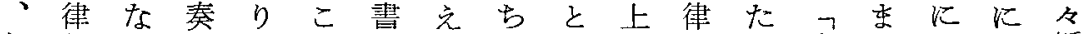

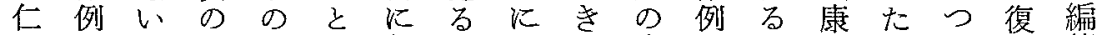

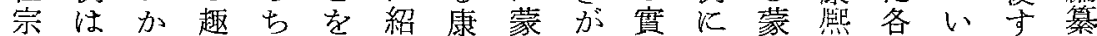
の蒙ら旨に想介臨古存例 は古三部てるさ 嘉古、飞屬起乙兵律しをじ閣六院のにれ 慶律なよすしたへ例た編香係へ全一到る

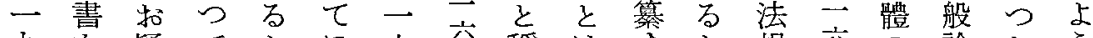

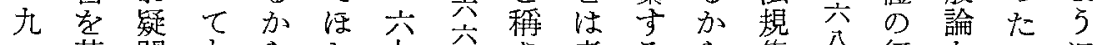
二基問当らし九交さ考る ら集公行をのに

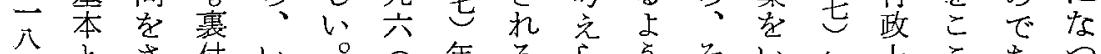

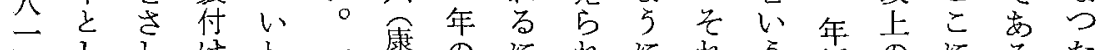

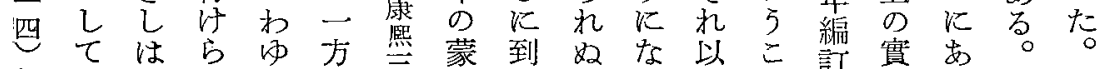

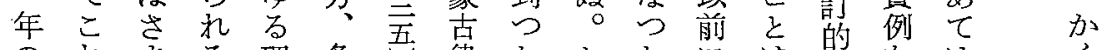
のれをる理各焉律たかたには理をは

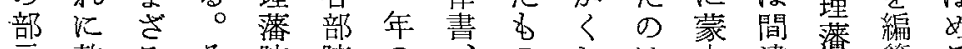

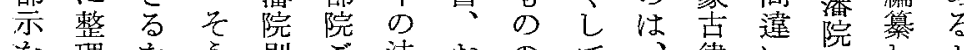
を理を 含を得す例と典よ前淸乾例な例た心 慶 导加なる の

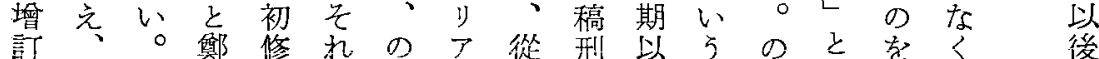
則高衍はどちザる 法後よみは則と

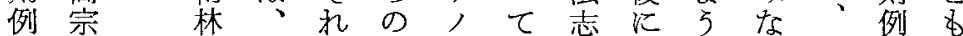
をの の嘉別蒙フい註屬なら占の全康 載乾 い慶々古スわにす名ずち書熈 世隆 5 三律

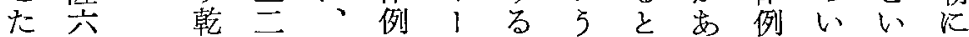
國 $=$ 隆こ行とが理 學士 鈔 $\vec{八}$ 政はツ藩康れたい雨た基

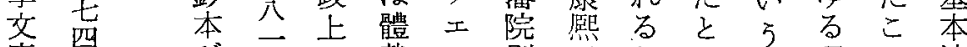

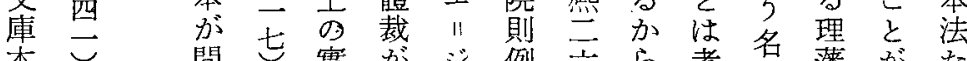
本こ問志實がシ例兵ら考名藩がた の年題年例異ヤで气、党は院明る 原初に刊を艺は六康らは則ら律

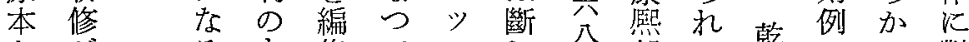

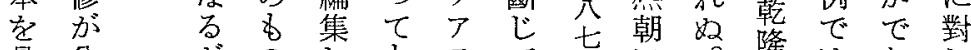

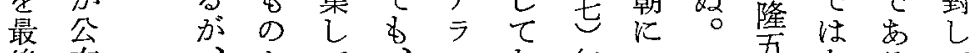
後布、をて瓜な年の一五なるるて

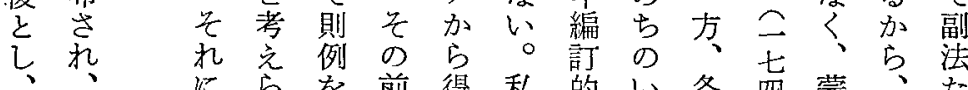
化占前得私的心各四蒙导

會 典 で 恦

乾

隆 曾 典 
蒙古律例と理藩院則例

b 應古定 律 簡の人書立、之院吉之述後例に方

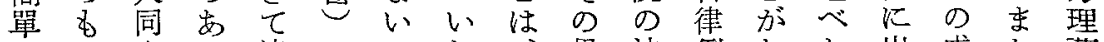
での志る渮のとわわ果法例あた出成た潘

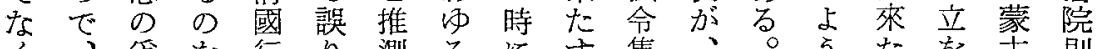

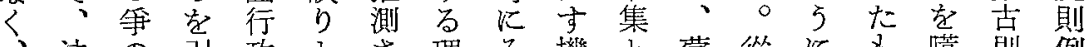

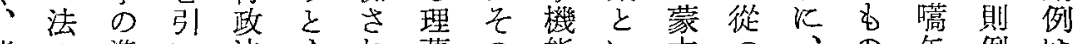
諸の準い法す机藩の能い克つ、の矢例柱

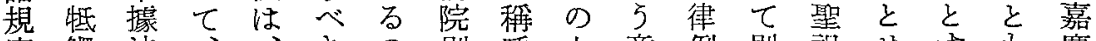

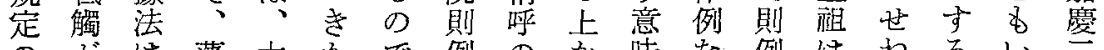
のがは藩大少で例の妿昧な例は的るい二

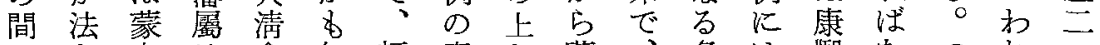
に古地會知輕 康古蒙: 名は熙なるれ 二

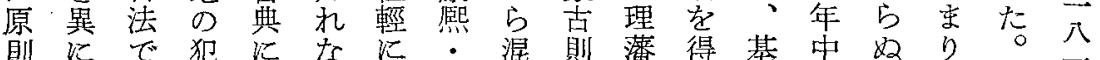
則にで犯にな 、る る

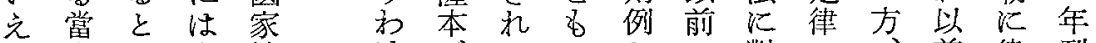

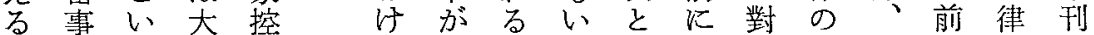

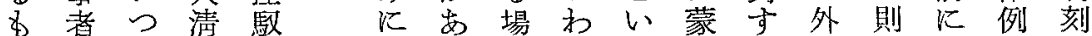
の間て律藩はる 合れわ古る條例清のさ は W例服 存例 $3 \hat{2}$ 以。

乙文。適仁 な涩为至 加蒙ち戔 古万憘 た人允杂笼 故漢 の、按 飞人之一蒙 ぞの沶應古 ち間りの士 らしで屬俗 の場起る安全酶 合㤎言定 古た、義 律

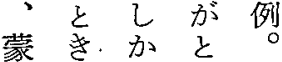
古、ᄂ 5 以 例矢屬就靖 之の人、邊 稱 具法從 微 さ體声? 二 れ 的義て 條決支古以 例深々 地と が必ま方心 重ずでで 親し—蒙 規

い子出たれ則補例と律名れ 加す岕のた例充のは沙た ずるりのこと法保行交出る 所得逆々呼—存政つ來 D 或說たでがば班市上てたが

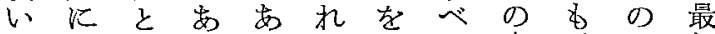

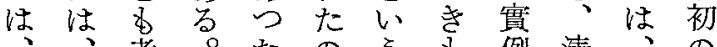
考。たの 5 名例清、の

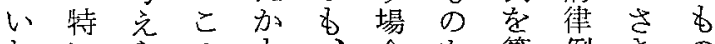
わにらの

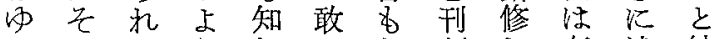
る の る 5 れ交刻し存述結 蒙所。以奴てう通たし穴論 古在從、。不た行必なた市

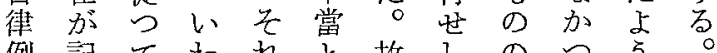

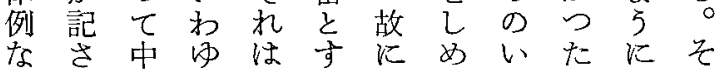
小礼國る市る 刑てい烹し 乙て邊蒙た法、以從宗て そ心疆古か當嫢こ佫つ蒙

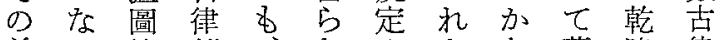
前心籍例、なや学な蒙隆律 身 點 䤿といw裁 見 5 古五例

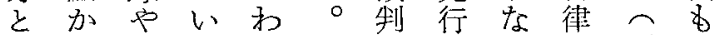

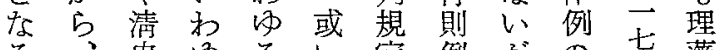

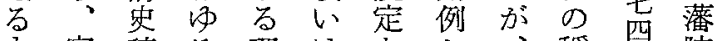

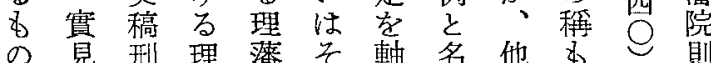
の見刑 理 藩 そ 軸名他蒠必年例

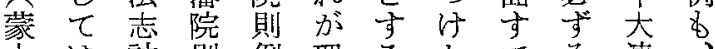
古は詿則例理るたでそ淸 


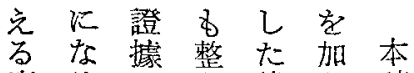
康ると交後帘稿

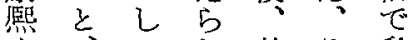
六、七れ乾々私 二蒙、ず隆机は、 六古皆蒙交はこ 七沙㲾を早机 對順例初く亦 年す治文修之元 蒙特 二名方名不

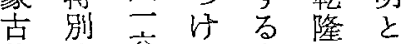
律法公 5 高五さ 書の吾れ宗これ

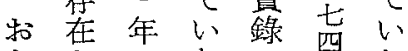
よをのたの び 前最吕記 蒙 り提初つ載年古 アとのたを高律 ザし律に探宗例 ノた レし容のと $>$ 增 化て $\tau$ 命

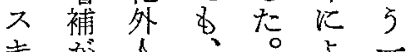
$\neq$ 加人。 I 加有聖年可? 方壳犯祖少、の 紹らしのと律體 介饥條康的济裁 乙たの㹂先條を た事 後年 $の$ 例整 二實 段 間 前を学 六学に焉身くた 杂擧、たとり法 六㖣世り考入令 康、宗に衣机集 㴍まのはらたが

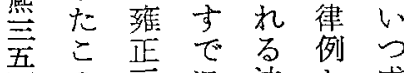
五の に法と成 年法乞市規い立 の規 $\overrightarrow{1} ら$ 集 5 し 法集士た法た 典を王 万、典か と 聖 5 \& の の 又祖年之ち體問 る 實以 しろ 裁 題 こ錄後、えがに とにのて體成檢 百見律 の 裁 立討

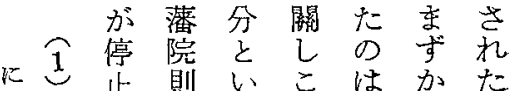
於焉例党の加。 清狆でな程以るそ 法行る

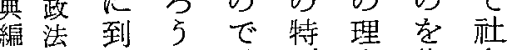
箱第 の-た考行法に成生 沿轮々政学上し活 革第制ら規公省よの 楊章幽 れ 定布と 5 實 鴻成与る桨し考と際 烈文る。主て光し - 法。從立拝占た和 中括子七机の心 國点刑注吉にて 法び理 法、。 ち生 律淺藩規だ蒙方起 發茾院定心古心し 迲虎則やた律なか 史夫例裁 势支の制にに。な ○郡公規招は刑拿 布定いる法に に学て ち 規處 上小 事万定 市

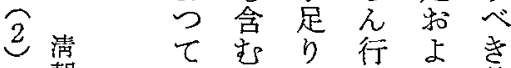

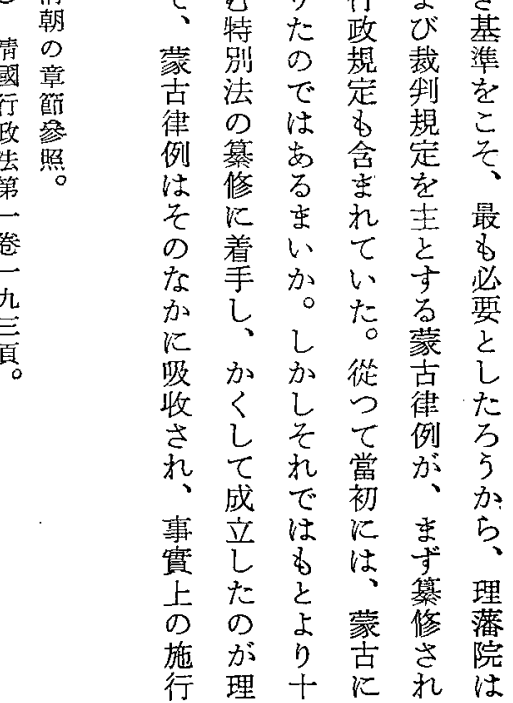




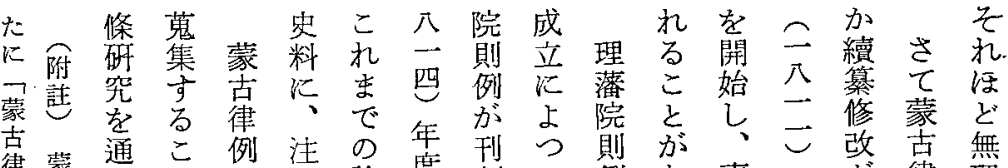

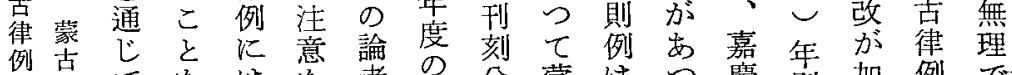

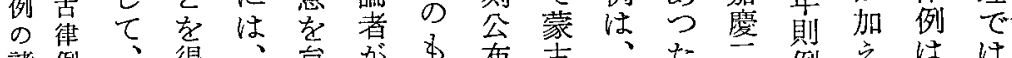

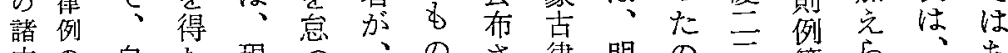

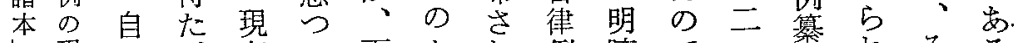

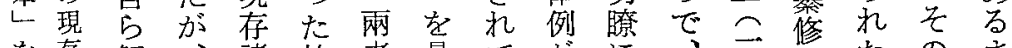
存解、諸故者最て占に元館たの立

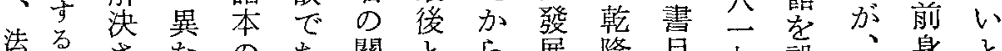
律墸されるの

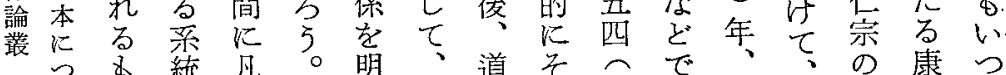
つ名統凡。明、道そこで、「の康つ。

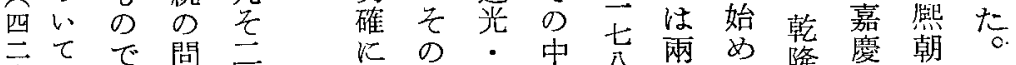

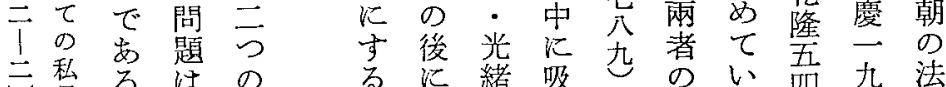

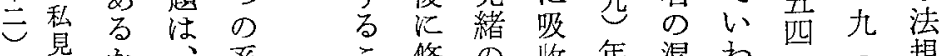

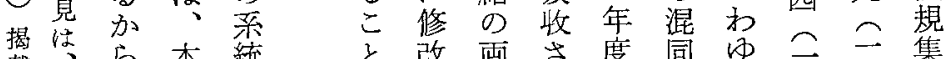
载、 5 本統改両さ度同ゆ气二集

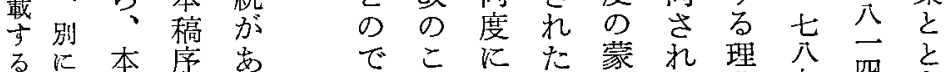

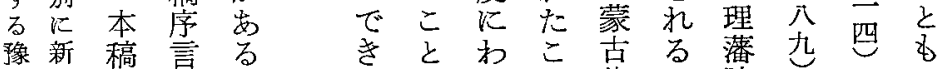

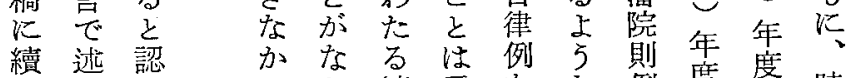
定いべぬ でてたら 要公私和 る表尛企学 号方企私 つ諸のは 心諭遂こ

$\tau$ 稿 行 れ 見 Kの 5 5 諒 過 諸 れ程 本 たこ隹を

具 $九$

で體 ら

は的吕

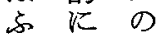
かなる は例 5 則度度 時

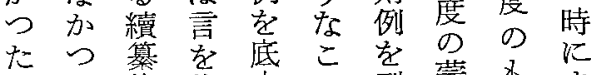
れは杜

な蒙た w古 b

。律 羊

の 許 逐江

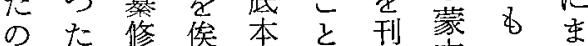
は事改たと名刻克のた 、實㤎なし市公則が蒙 專名ないて 希例最古 $5 、$ 筑得し卞後則 則以れま修たた。告例 例上たたさと。施認と 纂のの嘉れ考こちめ的 修所火慶た方の蒙ら呼 館論對三屯則克机注

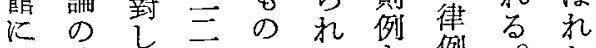
お傍、二でる。例。た け證蒙公市。委底方 ると古大る底方方 立卞律七吕時本、で 法茢もら埋を 事こは年、蒙し藩り 業学嘉最潘 克て則則完々 關で初院例例嘉の 聯き九 $九$ 則 $九$ 慶後 乙ょ儿理例 $心$ 纂二何 たら。藩のわ修六度 


\section{Report on Some Views of the Early Roman Family \\ by Yositaro Kosuge}

The author reviews the following works so far as concerns the subject : Westrup, Introduction to early Roman law II (1934) ; Levy, Neue Bruchstücke aus den Institutionen des Gaius, in SZ 54 (1934); Wieacker, Hausgenossenschaft u. Erbeinsetzung (1940); Betti, Das Wesen des altröm. Familienverbandes, in SZ 71 (1954); Kaser, Das röm. Privatrecht I (1955) 48-49 ; Yosino, Formation of the legal Concept "proximus adgnatus" in the Twelve Tables (in Japanese), in Senshu-daigaku-ronshu 20 (1959); Broggini, Vindex u. Iudex, in SZ 76 (1959) 123-129.

\section{Mêng-ku Lü-li and Li-fan-yuan Tse-li \\ by Masao Shimada}

In the Mêng-ku Lü-li and the Li-fan-yuan Tse-li, which are well known as the legislation enforced by the Ching dynasty on the Mongol tribes, are to be found laws and precedents originating from the Mongol law, such as penal regulations based on the principle of compensation, and the indigenous marriage regulations. These have been singled out and a comparative study made on the statutes of Western Mongolia-Oirät or Northern MongoliaKhalkah, of that time because it was thought that the legal usages of Inner Mongolia under the Ching dynasty rule could be redintegrated. In recent years, considerable interest has been aroused in the study of the original text of the Mogol statutes. By making profitable use of the findings, the writer plans to undertake the above study. However, in order to do so, there will be need to clarify the character of the Mêng-ku Lü-li and the Li-fan-yuan Tse-li, both of which will serve as criteria. Intended to serve as an introduction, so to say, to the above issues, this paper will proceed to make an exclusive discussion of the two statutes.

To date, it is not definitely known when the compendium of statutes appearing in the form of the Meng-ku Lü-li came into being. In this paper, the view is advanced that it actually assumed the semblance of a code referred to as $L \ddot{u}-l i$ by including precedents in the statutes, under instructions from KAO-Tsung, early in the 5th year of the Chien Lung era and most probably became law sometime between ' the 30th and 40th year of the above Chien Lung era. However, from the standpoint of the principle of personal jurisdiction, a compilation of precedents for the Mongol tribes in actual court proceedings was considered necessary, and it is presumed that, for this reason, a collection of laws and precedents, thought to be the forerunner of the Mêng-ku Lü-li, was already in use earlier than the Chien Lung era, in 
other words, about the middle of the Kang Hsi era. Furthermore, the Mêng-ku Lü-li apparently underwent revision a number of times until, in the 19th year of the Chia Ching era (1814), it assumed the form we know today. On the other hand, the Li-fan-yuan Tse$l i$ dates back to the 16 th year of the Chia Ching era, when the Tse-li Compilation Institute was established to undertake revision, and the law was promulgated in the 22nd year of the Chia Ching era (1816). This is considered the oldest legislation. Furthermore, it has been ascertained by means of historical records that the Mêng-ku Lü-li, prepared in the 54th year of the Chien Lung era (1789) has served as the original text for compilation of these statutes.

The Mêng-ku Lü-li incorporates a number of administrative regulations imposed by the Ching dynasty on. Mongol, as well as numerous penal and judicial regulations. On the other hand, the Li-fan-yuan Tse-li embodies administrative regulations over a wide scope, embracing the LAMA and Thibetan precedents, together with the Russian precedents, and even penal' and judicial regulations, the same as the Mêng-ku Lü-li. So far the connection between the two has not been clarified, but because of the fact that the initial compilation of the Li-fanyuan $T s e-l i$ was based on the original text of the Mêng-ku Lü-li; also, that, after completion of the Li-fan-yuan Tse-li, revisions were undertaken during the Tao Kuang and Kuang Hsü eras, whereas the Mêng-ku Lü-li has remained unchanged since the Chia Ching era (1814). The writer has thus' come to the conclusion that the Mêng-ku Lü-li. was absorbed in the $L i$-fan-yuan $T s e-i \dot{i}$, and became, in effect, defunct as a result. As, from the above, the nature of the legislation aimed at the Mongol tribes by the Ching dynasty has been clarified, the writer desires hereafter to make a study of the various provisions of the statutes, and to look into the substance of the Mongol law reflected therein, as well as the various. legal usages of the people of Inner Mongoria under the Ching. dynasty rule.

\title{
A Consideration concerning the Village System in Yuan (元) Period, observed through the Examples of the Form of the Contract
}

\author{
by Tomosaburō Niwa.
}

In Yuan (元) period; there were two kinds of the encyclopedia of daily use: "Xinbianshiwenleiyaoqizhaqingqian”（新編事交類要笅答青錢） (51 vols.) and “Xinbianshiwenlei -

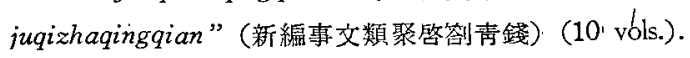

- The former was used from the end of the 13 th century till the first half of the 14th. century, the latter from the first half of the 14th century till the late Yuan (元) or the eary Ming (明) period:

Each of these books describes the 16 forms of the contract; for instance, the contracts on 